\title{
НАУЧНОЕ СООБЩЕНИЕ
}

\section{ПРАВОВОЕ РЕГУЛИРОВАНИЕ ПРОЦЕДУРЫ РАЗРЕШЕНИЯ НАЛОГОВЫХ СПОРОВ}

И.Л. Самсин

\begin{abstract}
Аннотация. В статье показана специфика правового регулирования процедуры разрешения налоговых споров. Автор выделяет его элементы и стадии, особое внимание при этом уделяется характеристике первой стадии, связанной с существованием нормы права, поскольку она закладывает основы в упорядочение процессуальных отношений; характер материальных отношений, которые должны получить определенную процессуальную форму, предрешает направленность процедурного регулирования, а вместе с ним - и принципы того или иного процесса. Движущей силой динамики налоговых споров, основанием перехода процессуальных отношений от одного этапа к другому выступают юридические факты. Исследуются проблемы, связанные с инициированием налогового спора, в частности возможности инициации последнего налоговым органом в связи с действием или бездействием плательщика налога, образующего правонарушение. Кроме того, рассматриваются вопросы обжалования решения налогового органа в судебном порядке.

На основании использования догматического метода исследования автор приходит к выводу, что налоговый спор: а) является отдельным правоотношением, не входящим в структуру налогового обязательства, но существенно влияющим на развитие налоговых обязательственных правоотношений; б) преимущественно происходит параллельно с последними, а не после их прекращения (исключение составляет отмена решения налогового органа о доначислении сумм налога, самостоятельно исчисленная сумма которого уже была уплачена налогоплательщиком).

Ключевые слова: налог, налоговый спор, налогообложение, налогообложение в Украине, налоговое обязательство, механизм регулирования споров, правовое регулирование, юридический факт, налоговый долг, судебное обжалование решения.
\end{abstract}

П равовое регулирование налоговых споров предполагает не только адекватное законодательное отражение, но и четкое методологическое представление о природе такого спора и принципов его решения. Принципиально важным является установление общей процессуальной формы и механизма регулирования этих отношений. Исходя из того, что механизм правового регулирования в общем виде можно рассматривать как систему правовых средств, определенным образом структурированную и согласованную, которая направлена на преодоление препятствий при удовлетворении интересов участников обще- ственных отношений, важна детализация элементов такого механизма.

На наш взгляд, логическую конструкцию соотношение элементов и стадий правового регулирования выделяет А.В. Малько. В частности, в механизм правового регулирования он включает: 1) норму права; 2) юридический фракт или фактический состав с таким решающим фрактом, как организационно-исполнительный правоприменительный акт; 3) правоотношение; 4) акты реализации прав и обязанностей.

Начальная стадия правового регулирования связывается с существованием нормы

(c) Самсин Игорь Леонович

* Кандидат юридических наук, судья Верховного Суда Украины

[Demodrei@inbox.ru]

Украина, 01043, г.. Київ, ул. П. Орлика, д. 4-а. 
права. Именно таким способом общие или ориентировочные пожелания к поведению участников приобретают определенную форму, которая, с одной стороны, направлена на реализацию интересов участников отношений, а с другой - должна найти свое место в четко структурированной системе права - соответствующем институте, подотрасли, отрасли.

Целесообразно на этой стадии, на наш взгляд, разграничивать регулятивное влияние материальных налоговых норм и процессуальных. Даже если рассматривать исключительно элементы механизма разрешения налоговых споров как определенного процесса, представляется необходимым начинать с анализа материальных правовых норм. Эта стадия регулирования закладывает фундаментальные основы в упорядочении процессуальных отношений. Именно ею формируются основы для защиты прав и интересов участников правоотношений, связанных с уплатой налогов и сборов. Качеством конструирования материальных налогово-правовых норм обеспечивается их логическое и эффективное действие, а соблюдение их гарантирует постоянство собственных налоговых поступлений государства и территориальных общин. Кроме того, характер материальных отношений, которые должны получить определенную процессуальную форму, предрешает направленность процедурного регулирования, а вместе с ней - и принципы того или иного процесса.

Налоговые процессуальные нормы, в свою очередь, акцентируют воздействие непосредственно на установку и обеспечение порядка разрешения налоговых споров. Реализация этого порядка осуществляется путем установления границ должного и возможного поведения обязанных участников и полномочий органов, которые представляют публичного субъекта, порядка совершения определенных процессуальных действий, ведения процесса.

Необходимой предпосылкой возникновения и развития налоговых споров является юридический факт. Главное назначение юридических фактов - «активация» всего механизма, введение соответствующих процессуальных норм в действие. До совершения определенного действия или наступления события, т.е. до реализации определенного юридического факта, процессуальные нормы существуют вообще, в теоретической плоскости. После того, как определенный законом юридический факт состоялся, положение процессуального закона начинают реально влиять на определенные отношения, на основании предписаний процессуальной правовой нормы наступают определен- ные последствия, осуществляется переход к следующим этапам динамики налогового процессуального регулирования. Юридические факты, таким образом, являются движущей силой динамики налоговых споров, основанием перехода процессуальных правоотношений от этапа к этапу.

В качестве инициатора налогового спора может выступать как плательщик налога, так и налоговый орган. В то же время нужно иметь В виду, что решение налогового спора по инициативе плательщика может осуществляться в двух различных режимах: путем административного обжалования и в суде. По инициативе налогового органа налоговый спор может решаться только в суде.

По мнению некоторых авторов, основанием возникновения налогового спора по инициативе налогового органа не могут быть действия или бездействие плательщика. Такой вывод базируется на том, что правонарушение, совершенное плательщиком, не является основанием возникновения спора, а в качестве последнего авторы выделяют решение о привлечении плательщика к ответственности. Нам сложно согласиться с таким выводом. Именно неправомерные действия (бездействие) плательщика являются тем юридическим фактом, который порождает расхождение в интересах и служит основанием для дальнейших действий сторон (уже в режиме налогово-правового спора), в том числе принятия соответствующего решения налоговым органом. В случае принятия неправомерного решения основанием для возникновения налогового спора будет именно решение налогового органа. Вместе с тем следует иметь в виду, что эти споры будут иметь разный предмет: первый - взыскание с налогоплательщика его налогового долга; второй обжалование неправомерного решения налогового органа. Таким образом, к юридическим фактам как к элементу механизма решения налогового спора следует также отнести решения налоговых органов.

Следующий элемент механизма разрешения налоговых споров, или стадия налогово-процессуального правоотношения, - это возникновение и развитие конкретной юридической связи участников отношений в условиях, когда обобщенное правовое предписание приобретает определенную юридическую упорядоченность при участии отдельных реальных субъектов. Именно на этом этапе реализуется основное количество процессуальных норм, регулирующих поведение участников правоотношений по решению налогового спора - двусторонних или трехсторонних (в слу- 
чае судебного спора). Эта стадия сочетает и итоговое значение, и соответствующее содержание, предусматривающее новый этап развития правового регулирования - возникновение акта реализации прав и обязанностей.

С одной стороны, акты реализации прав и обязанностей подводят определенную черту под оценкой в правовом смысле поведения лиц, происходившего до этого. С другой стороны, они же предусматривают последствия в виде корректировки поведения участников, отмены соответствующих решений или, наоборот, подтверждение правомерности их принятия. На этой стадии реализация субъективных прав и юридических обязанностей осуществляется таким образом, что позволяет удовлетворить интересы участников отношений.

Вместе с тем следует иметь в виду, что, учитывая несовпадение интересов, на основании которых возник тот или иной налоговоправовой спор, результат его решения не может в равной степени удовлетворить обе его стороны, и одна из них может сопротивляться выполнению определенного решения. В таком случае судебному разрешению налоговых споров может предшествовать, а то и полностью заменять его процедура административного обжалования. Она не является обязательной для плательщика и не лишает его права на судебное обжалование решений налогового органа даже в случае отказа в удовлетворении его административной жалобы.

Независимо от эффеективности административного обжалования решений контролирующих органов и результатов такого обжалования налогоплательщики всегда имеют право обратиться за защитой своих прав в суд. Не углубляясь в процедурные моменты, связанные с рассмотрением налоговых споров в судах, считаем целесообразным остановиться на вопросах значения этих процедур для динамики налогового обязательства.

Судебное обжалование решения налогового органа о доначислении суммы налога и штрафных санкций относится к процедуре согласования денежного обязательства, а поэтому скорее осуществляется на этапе изменения налоговых обязательственных правоотношений, чем их прекращения. Обжалование такого решения не является единственным предметом судебного рассмотрения дел, которые выливают из налоговых правоотношений. В частности, налогоплательщик может обжаловать решение налогового органа об отказе в принятии декларации или уточняющей декларации плательщика как документов налоговой отчетности. Предмет такого спора прямо вытекает из единой обязанности государства в налоговых обязательственных правоотношениях - принять исполнение налогового обязательства.

Исполнение налогового обязательства предполагает не только осуществление ряда действий со стороны налогоплательщика, но и принятие этих действий государством (или уполномоченным им органом) как положенных в пределах таких обязательственных правоотношений. Последнее осуществляется в пассивной фрорме (в виде принятия средств на счета казначейского органа, отчетных документов налогоплательщика в налоговый орган и т.д.) и требует проведения определенных формальных действий, которые не являются проявлением властной компетенции субъекта, а лишь удостоверяют факт выполнения плательщиком его обязанностей (например, выдача банковским учреждением квитанции об уплате сумм налога, копии отчетных документов с отметкой налогового органа об их принятии).

Другой предмет судебного рассмотрения споров, вытекающих из налоговых правоотношений, - принудительное взыскание налогового долга, непосредственно связан с выполнением налогового обязательства. Исходя из того, что налогоплательщику даже в случае ошибки или других оснований ненадлежащего исполнения им налогового обязательства закон предоставляет широкие возможности исполнить обязанность по уплате налога до судебного решения, можно сделать вывод о том, что подавляющее большинство ответчиков по такой категории споров - недобросовестные налогоплательщики. Последние либо умышленно уклоняются от исполнения налогового обязательства, или не имеют возможности оплатить налоговый долг, возникший изза трудного материального положения.

В любом случае речь идет об уже согласованной сумме денежного обязательства, а также пени, поскольку плательщик-ответчик не выполняет добровольно обязанность по уплате налога, а следовательно, нарушает установленные законом сроки его уплаты. Вряд ли можно назвать такое дело публично-правовым спором в подлинном смысле этого слова, даже учитывая положения Кодекса административного судопроизводства Украины. Фактически предметом доказывания в таком деле является лишь наличие или отсутствие налогового долга у плательщика, даже если такой долг возник не на основании незаконного решения налогового органа. Если налогоплательщик не воспользовался своим правом на обжалование такого решения, он автоматического согласился с из- 
менением объекта налогового обязательства, в то время как его обязанности по уплате его практически не изменились.

По результатам рассмотрения административного дела о взыскании налогового долга суд в случае подтверждения наличия последнего принимает постановление, которым взимает с плательщика сумму налогового долга. Однако налоговое обязательственное правоотношение не прекращается вступлением в законную силу решения суда. После вступления решения в законную силу плательщик также имеет выбор между добровольным исполнением решения о взыскании соответствующей суммы и выполнением его в принудительном порядке.

Стоит заметить, что принудительное исполнение решения суда осуществляется органами государственной исполнительной службы, которая является субъектом властных полномочий в понимании Кодекса административного судопроизводства Украины, а соответственно ее действия, решения и бездействие также подлежат судебному обжалованию в порядке административного судопроизводства. Поэтому весьма важным при исполнении решения суда о взыскании налогового долга является соблюдение процедуры, установленной законом. Безусловно отношения принудительного исполнения решения суда по своей природе не являются налоговыми, но влияют на динамику налогового обязательства, ведь даже в случае принудительного исполнения юридическим фактом, который указывает на прекращение налоговых обязательственных правоотношений, признается фрактическое перечисление суммы налога, который входит в состав налогового долга, на соответствующие счета.
В случае отказа в удовлетворении административного иска налогового органа о взыскании налогового долга объект налогового обязательства не меняется. В соответствии с этим налоговое обязательство считается исполненным в момент уплаты первоначальной суммы налога, а если такая уплата не состоялась до вступления в законную силу решения суда, налоговое обязательство подлежит исполнению в общем порядке. В случае признания доначисления сумм налога противоправным подлежат отмене и все способы обеспечения исполнения денежного обязательства, которое было доначислено, в том числе и пеня, начисленная на сумму такого денежного обязательства.

Учитывая изложенное, можно сделать вывод о том, что налоговый спор является отдельным правоотношением, которое не входит в структуру налогового обязательства, но результаты которого существенно влияют на развитие налоговых обязательственных правоотношений. Кроме этого, стоит отметить, что налоговый спор преимущественно происходит параллельно с налоговыми обязательственными правоотношениями, а не после их прекращения. Исключением из этого правила может быть разве что отмена решения налогового органа о доначислении сумм налога, самостоятельно исчисленная сумма которого уже была уплачена плательщиком. В таком случае обязательство считается исполненным в день первичной уплаты суммы налога, а отмены решения налогового органа, т.е. окончание спора, происходит позже. Во всех других случаях прекращение спорных правоотношений предшествует уплате сумм налога, а следовательно, и выполнению налогового обязательства.

\section{Библиография:}

1. Коваленко С.А. Налоговые споры: понятие и основания возникновения // Налоговые споры: теория и практика. - 2004. - № 9.

2. Семушкин В.С., Воробьева Ю.В. К вопросу о понятии и основаниях возникновения налоговых споров // Налоговые споры: теория и практика. - 2004. - № 12.

\section{References (transliteration):}

1. Kovalenko S.A. Nalogovye spory: ponyatie i osnovaniya vozniknoveniya // Nalogovye spory: teoriya i praktika. - 2004. - № 9.

2. Semushkin B.C., Vorob'eva Yu.V. K voprosu o ponyatii i osnovaniyakh vozniknoveniya nalogovykh sporov // Nalogovye spory: teoriya i praktika / V.S. Semushkin, Yu.V. Vorob'eva. - 2004. - № 12. 